\title{
The American Review of Politics is Seeking a New Editor
}

The American Review of Politics is currently published through the Department of Political Science at the University of Arkansas. The journal covers an array of topics in American politics, but has focused in recent years more heavily on political parties and Southern politics.

Given the wide range of articles included in the journal, the editor is expected to be an established scholar who understands the breadth of the American politics field and be conversant and knowledgeable about the diverse scholarship of this field. The editor is expected to be responsive to the individuals who submit manuscripts to the journal and able to provide constructive feedback to those individuals. In addition, the editor will be responsible for a variety of organizational and managerial functions associated with editing a journal. These will include appointing members of the editorial board, appointing associate or co-editors, appointing a book review editor, soliciting manuscripts for publication, and maintaining subscription and financial records for the journal.

The current publication cycle includes one print run that combines both spring and summer issues and a second printing including the fall and winter issues. The current editorial team will publish the journal through Volume 34, which will cover the Fall 2013 and Winter 2014 issues. The new editor and staff will be responsible for soliciting manuscripts for and publication of the Spring and Summer 2014 issues.

Interested individuals should provide a vita, a statement of interest describing their vision for the journal, and a letter of support from the host institution. Please contact Andrew Dowdle, 428 Old Main, Department of Political Science, University of Arkansas, Fayetteville, AR 72701 or via email to adowdle@uark.edu. 